\title{
OBSERVATION OF TAXONOMIC FEATURES OF A TERRESTRIAL ALGAE OEDOCLADIUM TERRESTRE BISWAS (CHLOROPHYCEAE) WITH SOIL ANALYSIS FROM WEST BENGAL, INDIA
}

\author{
NILU HALDER \\ Department of Botany, Raja Peary Mohan College, Uttarpara-712258, Hooghly, W.B., India \\ niluhalder75@gmail.com
}

\section{ABSTRACT}

In the present paper, a brief description along with valuable information of Oedocladium terrestre Biswas, a member of Oedogoniales of Chlorophyta, has been provided. This species was collected from a velvety green patches on damp soil at Jirat of Hooghly district, West Bengal, India. The bending of mature oogonium downwardly was an interesting feature that might be due to easy entry for gametes within this female structure. This character is appeared to be an ecological adaptation for terrestrial habitat. In addition to that, presence of narrower rhizoids in the thallus that helps penetrating, anchoring and absorbing water and mineral contents from soil also supported the terrestrial adaptation of this taxon. This is a rare algal taxon. The soil analysis of the algal distribution site showed the following features as: sand $(36.1 \%)$, silt (28.1\%), clay (35.8\%), pH (7.1), EC (0.154 dSm$\left.{ }^{-1}\right), \mathrm{OC}\left(6.7 \mathrm{mgkg}^{-1}\right), \mathrm{Ca}^{2+}\left(4.8 \mathrm{cmol}^{+} \mathrm{kg}^{-1}\right), \mathrm{Na}^{+}$ $\left(0.72 \mathrm{cmol}^{+} \mathrm{kg}^{-1}\right), \mathrm{K}^{+}\left(0.16 \mathrm{cmol}^{+} \mathrm{kg}^{-1}\right), \mathrm{WHC}(47 \%)$ and total S $\left(98.2 \mathrm{mgkg}^{-1}\right)$.

Keywords: taxonomy, Oedocladium terrestre, rare alga, oogonium,soil analysis, west Bengal, India

\section{INTRODUCTION}

Chlorophyceae (green algae) is one of the largest groups among the algal floral composition in West Bengal, India. The members exhibit diversities in thallus organization, from unicellular, colonial to filamentous and higher levels of tissue organization (pseudoparenchymatous/ parenchymatous or thalloid) and branching morphologies (Lewis \& McCourt, 2004). The genus Oedocladium is established by Stahl in 1891 under the family Oedogoniaceae and order Oedogoniales of class Chlorophyceae. Since its establishment, the genus is represented by eleven species from different parts in the world (Islam, 1962). At present, There are 16 species (and infraspecific) names in the algal database, of which taxonomically accepted species of this genus are fifteen and they are distributed world widely in South-West Asia like India (Ettl \& Gärtner, 1995) and Bangladesh, USA, Australia, Germany, Brazil (Guiry \& Guiry, 2016). In India, the species of Oedocladium Stahl are very rare (Randhawa, 1941). The phylogeny of Oedogoniales using nuclear $18 \mathrm{~S}$ rDNA sequences revealed that the genus Oedocladium Stahl is a separated clade and is clustered within the clade of Oedogonium Link ex Hirn (Mei et al., 2007). Species of this genus may be monoecius or dioecious. Among the explored species, most of them are terrestrial except Oedocladium hazenii I. F. Lewis. Apical growth 
of the filaments takes place by the divisions of terminal cells of filaments and the formation of a branch occurs by the development of a circular rent in the upper extremity of a vegetative cell. A single division of vegetative cell also results the formation of oogonium. Antheridium usually occurs on lateral branches. Asexual reproduction takes place by means of akinetes and zoospores. Holdfast cell is absent and resting cells or akinetes are produced on the rhizoidal filaments (Tiffany, 1930).

This alga is filamentous and branched. The rhizoidal portion is found attached with the upper soil surface in wet environment. In the young stage, it looks bright green in colour and at older stage it becomes brownish-green. During the algological study, it is found that the taxon initiates to grow in the month of July (rainy season) and subsequently reached its maximum with reproductive structures (mature oogonium and antheridium) in middle to late August although, it continues to grow still on October (before winter). This prolonged growth phase is probably due to availability of sufficient water and minerals from damp soil followed by the monsoon.

Few scientific papers on the taxonomy and distribution of this algal genus have come out from India. Biswas, (1936) first recorded a new species of Oedocladium namely O. terrestris Biswas in Calcutta, West Bengal from Indian subcontinent. Randhawa (1941) reported Oedocladium himalayense Randhawa and Oedocladium operculatum Tiffany from Himalaya range of Kumaon, India. He collected those two species at the time of a tour during September and October in 1939. Next, Randhawa (1958), further, described with illustrations of $O$. terrestris Biswas emend. Randhawa raised questions in view of recognition it as a nannandrous species. Gonzalves \& Yalavigi (1956) gave a note on the occurrence of Oedocladium operculatum Tiffany in soil sample from Dharwar, Karnataka, India. Followed them, Lakshminarayana (1969) had also reported occurrence of Oedocladium terrestre (Biswas) Randhawa from Andhra Pradesh, South India. Singh et al. (1981) described eight interesting algae including Oedocladium terrestre (Biswas) Randhawa from Allahabad, Uttar Pradesh, India for the first time. They again described Oedocladium prescottii Islam, for the first time from Uttar Pradesh, India. Das \& Sahu (1990) during the survey of algal flora of Chotanagpur, Jharkhand recorded 20 members of Oedogoniales. Among them, one taxon of Oedocladium Stahl showed some variations in the morphological features from the type species and they reported it as a new species as O. oominilateralis Das and Sahu from this locality. Latter, Mahato (1998) also documented a new species of this genus namely Oedocladium randhawae Mahato collected form moist soil of Munger in Bihar, India.

Soil is one of the most important and valuable resource in the earth. It serves as a natural medium for the growth of plants and is influenced by several environmental factors (Manimegalai \& Sukanya, 2014). Physical, chemical and biological properties of soils depend on soil textures and mineral contents (Sumithra et al., 2013). As, the algal species were grown on soil surfaces and physico-chemical properties of soil helped its occurrence and growth henceforth, soil analysis of some parameters was done to assess the quantities and influences of those parameters. Besides these, taxonomical and distributional information regarding this species are still meager from eastern part of India. For those reasons, the present work was carried out. 


\section{MATERIALS AND METHODS}

The algal sample was collected in a glass container from a paddy field during monsoon i.e. in the month of August, 2012 (on 21.08.2012) from Jirat (22 $33^{\prime} \mathrm{N}, 7^{\circ} 76^{\prime} \mathrm{E}$ ) at an elevation of 14.59 meters above sea level in Hooghly, west Bengal, India. Algal sample was preserved in $4 \%$ formalin solution and the voucher specimen was deposited in the Departmental Herbarium of the Department of Botany, Raja Peary Mohan College, Uttarpara, west Bengal. Microscopic study was done under Olympus microscope (Model-CH20i). Identification of this taxon has been made with scientific literatures and standard monograph viz. Biswas (1936), Randhawa (1958), Lakshminarayana (1969), Gonzalves (1981).

Soil sample from a depth of $15 \mathrm{~cm}$ was collected; air dried and brought up to the laboratory for estimation of various physico-chemical parameters of soils. To obtain clear supernatant of soil sample centrifugation at $2000 \mathrm{rpm}$ for 10 minutes was carried out by a Remi centrifuge (model, R-23). The Munsell colour charts (Munsell colour Co., 1975) was used to identify the colour of soil. Soil texture (particles size distributions) as percentages of sand, silt and clay fractions was determined by the hydrometer method followed by Bouyoucos (1962). The $\mathrm{pH}$ of the soil sample was recorded with the help of a pH meter (Jenway 3510). Electrical conductivity (EC) of soil suspension was measured by a direct reading conductivity meter (Systronic 303). The organic carbon $(\mathrm{OC})$ content of the soil sample was measured following the procedure of Walkey and Black (1934). Calcium $\left(\mathrm{Ca}^{2+}\right)$ was estimated by EDTA titration method of Chapman (1965). The sodium $\left(\mathrm{Na}^{+}\right)$and potassium $\left(\mathrm{K}^{+}\right)$values of soil were recorded by a flame photometer (Systronic, 121). Water holding capacity (WHC) was determined following the method of Piper (1966). Total sulphur (S) content was measured according to acid digestion method as mentioned by Tabatabai (1982). All the statistical analyses were done using the statistical software (SPSS v. 13, Inc., USA).

\section{RESULTS AND DISCUSSION}

Morpho-taxonomic description of Oedocladium terrestre Bisaws under light microscopic study had been provided here. Systematic position of the taxon was mentioned according to Smith (1950).

Division: Chlorophyta; Order: Oedogoniales; Family: Oedogoniaceae

\section{Genus: Oedocladium Stahl}

Oedocladium terrestre Bisaws in Rev. Alg. 10: 343, pl. 21, 1938 (figs 1\& 2)

Randhawa in Bot. Gaz. 120: 28, figs 18-24, 1958; Lakshminarayana in Phykos 8 (1, 2): 103104, figs 1-3, 1969; Gonzalves, Oedogoniales 685, fig. 11.10, 1981

Taxonomic Description: Thallus macrandrous, monoecious, terrestrial, filamentous, branched and rhizoidal; rhizoid narrower, sparingly branched, subterranean and hyaline; vegetative cell light or pale green, cylindrical, 35.0-45.0 $\mu \mathrm{m}$ in length, 12.0-14.0 $\mu \mathrm{m}$ broad; terminal cell with conical apex or obtusely rounded cap; pyrenoids 1 - 2 in each cell; oogonium solitary, terminal, bends downwards and sub-globose or ellipsoid-spherical on short lateral branch; 38.0-44.0 $\mu \mathrm{m}$ in length, 36.0-46.0 $\mu \mathrm{m}$ broad; operculum superior; oospore globose or ovoid, almost filling the oogonium; 28.0-34.0 $\mu \mathrm{m}$ in length, 30.0-35.0 $\mu \mathrm{m}$ broad; oospore wall smooth, brown when mature; antheridium hypogynous and 1-4. 
Habitat: It grows on damp soil at Jirat, Hooghly, west Bengal, India

Specimens examined: Jirat, Hooghly, WB, $14.59 \mathrm{~m}, 2^{\circ} 33^{\prime} \mathrm{N}, 75^{\circ} 76^{\prime} \mathrm{E}, 21.08 .2012$, Halder, NH1222 (RPM College, WB).

Phenology: July-October (monsoon)

Distribution: It is only restricted in Asia: India (West Bengal, Andhra Pradesh, Uttar Pradesh).

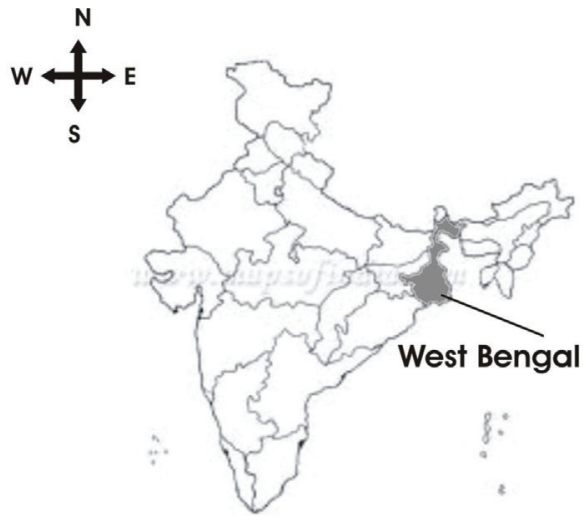

MAP OF INDIA
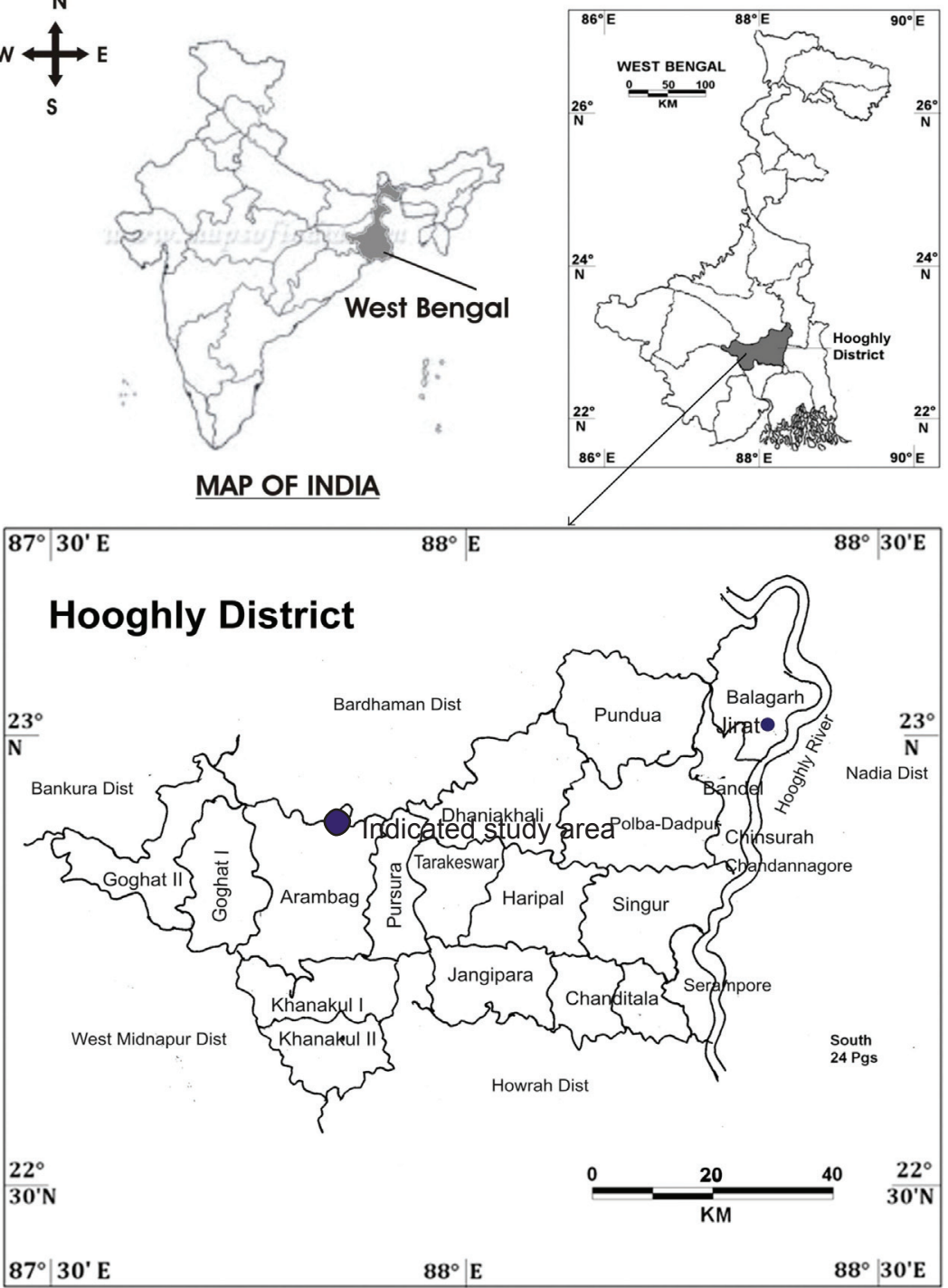


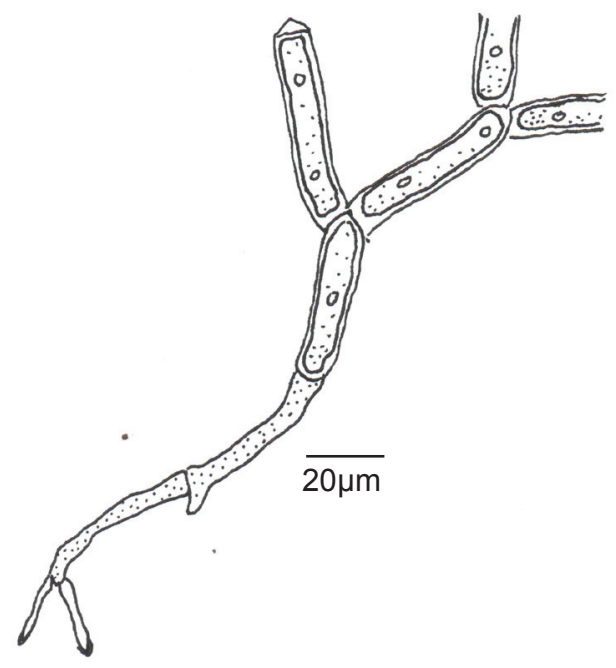

FIG. 1. Oedocladium terrestre vegetative filament with rhizoid.

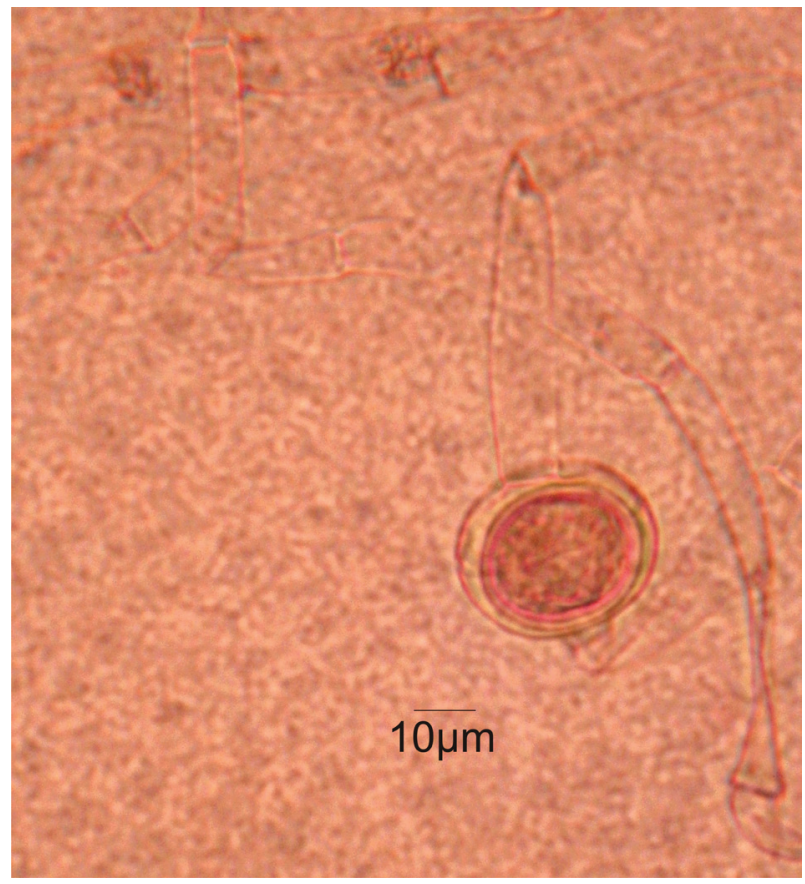

FIG. 2. Oedocladium terrestre filament with oogonium. 
TABLE 1. Physicochemical properties (Mean \pm SE) of soil at the time of algal species collection.

\begin{tabular}{|c|c|}
\hline Physicochemical properties & Results/Values (Mean \pm SE) \\
\hline Colour & Yellowish-brown \\
\hline Texural class & Clay-sandy loam \\
\hline Sand (\%) & $36.1 \pm 0.4$ \\
\hline Silt (\%) & $28.1 \pm 0.3$ \\
\hline Clay $(\%)$ & $35.8 \pm 0.4$ \\
\hline $\mathrm{pH}$ & $7.1 \pm 0.05$ \\
\hline $\mathrm{EC}\left(\mathrm{dSm}^{-1}\right)$ & $0.154 \pm 0.1$ \\
\hline $\mathrm{OC}\left(\mathrm{mgkg}^{-1}\right)$ & $6.7 \pm 1.2$ \\
\hline $\mathrm{Ca}^{2+}\left(\mathrm{cmol}^{+} \mathrm{kg}^{-1}\right)$ & $4.8 \pm 1.6$ \\
\hline $\mathrm{Na}^{+}\left(\mathrm{cmol}^{+} \mathrm{kg}^{-1}\right)$ & $0.72 \pm 0.05$ \\
\hline $\mathrm{K}^{+}\left(\mathrm{cmol}^{+} \mathrm{kg}^{-1}\right)$ & $0.16 \pm 0.1$ \\
\hline WHC (\%) & $47 \pm 0.3$ \\
\hline total $\mathrm{S}\left(\mathrm{mgkg}^{-1}\right)$ & $98.2 \pm 1.7$ \\
\hline
\end{tabular}

Each value was expressed with mean value \pm standard error of at least four replicates.

Documentation, systematic description and reporting or rereporting of any species from anywhere have enormous importance in the floristic work for the exploration of algal floral composition (Rai, 2012; Rai \& Misra, 2012; Bajpai et al., 2013; Singh et al., 2014; Srivastava et al., 2014; Halder, 2015 a, b). The present specimen is resembled with the type specimen in most of the essential morphological characters like occurrence, colour and organization of rhizoidal filaments; measurements of vegetative cells, number of pyrenoids in each cell and dimensions of reproductive structures particularly in respect of oogonium, oospore and nature of oospore wall as well as position of oogonium. Although, Biswas (1936) described this taxon as nannandrous species and he found oogonium as poriferous and pore was superior. Lakshminarayana (1969) while working on the occurrence of Oedocladium terrestre (Biswas) Randhawa from Andhra Pradesh, India noticed that mature oogonium was slightly bending towards soil surface and oogonium was operculate. In this study same features were observed. Previously, Singh et al. (1981) collected this algal species from patches on soil. The author also recorded this species from paddy field soil in Hooghly, WB, India. Thus, the taxonomic study confirmed the earlier findings.

The physicochemical parameters of soil of the sampling site at Jirat, Hooghly, West Bengal were presented in table 1. The colour of soil was yellowish-brown and the texture of soil was clay-sandy loam. Soil texture components were found as followed: sand: $36.2 \%$, silt: $28.1 \%$ and 
clay: $35.7 \%$. pH was slight alkaline (7.1). Electrical conductivity (EC) value was $0.154 \mathrm{dSm}^{-1}$. Organic carbon (OC) in the form of organic matter was recorded as $6.7 \mathrm{mgkg}^{-1}$. The essential nutrient contents like $\mathrm{Ca}^{2+}, \mathrm{Na}^{+}$and $\mathrm{K}^{+}$were measured in good quantities that supported the growth and development of this soil borne algal species. Water holding capacity (WHC) of the soil was determined as $45 \%$. Sulphur (S) is an important element for all biological organisms and is required for optimal plant growth (Moris \& Shin, 1988; Giri et al., 2011) and it exists primarily as organic and inorganic forms in the soil (Ogeh et al., 2012). The total sulphur content was observed $98.2 \mathrm{mgkg}^{-1}$ that indicated the richness of sulphur in the soil. Therefore, this result of soil analysis reflected that soil was highly fertile, clay-loamy, alkaline and rich in sulphur as compared to other nutrients.

Based on the present result, it may be concluded that this species was soil borne and grew in rainy season. It is filamentous, greenish, branched and attached to the soil surface with root like rhizoids. In maturity, it forms reproductive structures like oogonium and antheridium. It showed terrestrial adaptations for better growth and distribution and, prefer to grow in alluvial soil rich in sulphur contents. This is the first record of this taxon from Hooghly district, West Bengal, India. The present work will be helpful for further studies regarding floristic composition of algal flora and assessment of soil parameters from this area.

\section{REFERENCES}

BAJPAI, O; MISHRA, S; MOHAN, N; MOHAN, J; GUPTA, R K (2013) Physico chemical charecteristics of Lakhna Devi temple water tank, Lakhna, Bakewar, Etawah, U.P. with reference to Cyanobacterial diversity. International Journal of Environment 1(1): 20-28.

BISWAS, K (1936) A new nannandrous Oedocladium from India. Revue Algologique 10(1-4): 341-345.

BOUYOUCOS, G J (1962) Hydrometer method improved for making particle size analysis of soils. Agronomy Journal 54: 464-465.

CHAPMAN, H D (1965) Cation exchange capacity. In Methods of soil analysis. American Society of Agronomy (Black, C.A., L.E. Ensminger and F.E. Clark (Eds.). Inc, Madison, Wisconsin, USA; pp 891-901.

DAS, S N; SAHU, R (1990) A note on the occurrence of a new species of Oedocladium from Ranchi. Journal of Indian botanical Society 69: 473-474.

GIRI, PK; SAHA, M; HALDER, M P; MUKHERJEE, D (2011) Effect of pesticides on microbial transformation of sulphur in soil. International Journal of Plant, Animal and Environmental Sciences 1(2): 115-121.

GONZALVES, E A; YALAVIGI, V S (1956) A note on the occurrence of Oedocladium operculatum Tiffany in Dharwar soils. Journal of Karnataka University 1: 103-104.

GUIRY, M D; GUIRY, G M (2016) Algaebase. Worldwide electronic publication, National University of Ireland, Galway (http://www.algaebase.org.).

HALDER, N (2015a) Two species of Zygnemopsis (Skuja) Transeau from West Bengal, India. Tropical Plant Research 2(2): 82-84.

HALDER, N (2015b) Morpho-taxonomy of Hydrodictyon reticulatum (L.) Lagerheim and Pediastrum tetras var. tetraodon (Corda) Hansgirg, Hooghly, West Bengal, India. Tropical Plant Research 2(3): 168-171.

ISLAM, A K M N (1962) A new species of Oedocladium from East Pakistan with notes on the genus. Transactions of the American Microscopical Society 81(4): 372-379. 
LAKSHMINARAYANA, S (1969) On the occurrence of Oedocladium terrestre (Biswas) Randhawa from Andhra Pradesh, South India. Phycological society of India 8(1-2): 103-104.

LEWIS, L A; MCCOURT, R M (2004) Green algae and the origin of land plants. American Journal of Botany 91(10): 1535-1556.

MAHATO, A K (1998) A new species of Oedocladium from Munger, Bihar, India. Phytomorphology 48(4): 411-416.

MANIMEGALAI, K; SUKANYA, S (2014)Assessment of physico-chemical parameters of soil of Muthannan Kulam wetland, Coimbatore, Tamil Nadu, India. International Journal of Applied Sciences and Biotechnology, 2(3): 302-304.

MEI, H; LUO, W; LIU, G X; HU, Z Y (2007) Phylogeny of Oedogoniales (Chlorophyceae, Chlorophyta) inferred from 18S rDNA sequences with emphasis on the relationships in the genus Oedogonium based on ITS-2 sequences. Plant Systematics and Evolution 265(3): 179-191.

MORRIS, R J; SHIN, J S (1988) Sulphur, the fourth major plant nutrient. Proceedings of International Symposium on Sulphur for Korean Agriculture, Seoul, Korea; pp 9-16.

OGEH, J S; UZU, F; OBI-IJEH, O D (2012) Distribution of sulphur in soils formed from different parent materials in southern Nigeria. Nigerian Journal of Basic and Applied Science 20(1): 73-77.

Piper, C S (1966) Soil and plant analysis. Hans Publishers, Bombay, India; pp 223-237.

RAI, S K (2012) Five new species of Oedogonium Link (Chlorophyta), a freshwater filamentous algae from Nepal. Nepalese Journal of Biosciences 2: 17-23.

RAI, S K; MISRA, P K (2012) Taxonomy and diversity of genus Pediastrum Meyen (Chlorophyceae, algae) in east Nepal. Our Nature 10: 167-175.

RANDHAWA, M S (1941) Notes on three species of Oedocladium from the Himalayas. Transactions of the American Microscopical Society 60(4): 417-420.

RANDHAWA, M S (1958) Notes on some new algae from India. Botanical Gazette 120: 25-31.

SINGH, A; TIWARI, V; MOHAN, J (2014) Chroococcales in River Ganga at JajmauGhat, Kanpur. Tropical Plant Research 1(1): 28-30.

SINGH, S P; TIWARI, G L; PANDEY, D C (1981) Some interesting algal flora from Allahabad. Phycological society of India 20: 85-90.

SINGH, S P; TIWARI, G L; PANDEY, D C (1983) New record of Oedocladium prescottii Islam from Uttar Pradesh. Phycological society of India 22(1-2): 128-129.

SMITH, G M (1950) The freshwater algae of the United States. McGraw-Hill, New York, New York, USA. pp.1-718.

SRIVASTAVA, N; SUSEELA, M R; TOPPO, K (2014) Fresh water Cyanobacteria of Sai River near Lucknow, Uttar Pradesh. Tropical Plant Research 1(2): 11-16.

SUMITHRA, S; ANKALAIAH, C; RAO, D; YAMUNA, R T (2013) A case study on physico-chemical characteristics of soil around industrial and agricultural area of Yerraguntla, Kadapa district, A. P, India. International Journal of Geology, Earth and Environmental Sciences 3(2): 28-34.

TABATABAI, M A (1982) Sulfur. In Page, A L; Miller, R H; Keeney, D R (eds). Methods of soil analysis. Part II. Agronomy 9: 501-38.

TIFFANY, L H (1930) The Oedogoniaceae. Ohio State University Press, Columbus; pp 1-253. 